\title{
Impact of Oil Price Fluctuations on Returns of Different Sectors of Malaysian Stock Market
}

\author{
Atousa Jafarian \\ University Putra Malaysia, Serdang, Malaysia \\ Meysam Safari \\ SEGi University, Kota Damansara, Malaysia
}

\begin{abstract}
Oil price fluctuations affect equity values in North American, European, and Gulf Cooperation Council (GCC) stock markets, as evidenced by prior studies. However, they only focus on market-wide level analysis. This study, through both market level and sector level analyses, examines the sensitivity of Malaysian stock returns to oil price fluctuations over the period from January 2000 to March 2014. A multifactor market model has been employed to capture this sensitivity. The regression results show a positive impact of oil price changes on the Financial Times Stock Exchange Kuala Lumpur Composite Index (FTSE KLCI) market return. Consumer staples and energy sector index returns were also positively affected by oil price changes. On the other hand, utilities and telecom services were negatively affected over the study period. Moreover, Granger causality analysis was performed to see if oil price fluctuations Granger cause the stock indices to change. With one month lag period, oil price fluctuations Granger cause consumer staple, energy, industrials, and telecommunication services return. Relevant policymakers and market caretakers (Ministry of Finance, Central Bank, and Security Commission) may use the findings of this study to develop and incorporate a preventive mechanism to minimize the unfavorable impacts of oil price fluctuations on different sectors of stock market, and Malaysian economy in general.
\end{abstract}

Keywords: oil price, stock market, Malaysia, sectoral analysis, market sectors, energy

\section{Introduction}

Oil, as a major source of energy, has a strategic role in global economy. Oil price fluctuation in past few decades is not only the outcome of disparity between supply and demand for this critical commodity, but also many geopolitical factors. Fast paced economic growth of many developing countries, on top of the already-high energy consumption of developed economies, added to the ever-increasing demand for oil around the world. Oil price movement, hence, is affected by and is affecting the economies of virtually all countries. An increase in oil price affects economy in several ways, most importantly by increasing the inflation. At the consumer level, an increase in the oil price (i.e., cost of energy) may result in a reduction in the amount of consumption, or an increment in the total cost of production. In both cases, the earnings of oil consumers will be adversely affected. This study aims to investigate the effect of oil price movement on various sectors of Malaysian economy.

\footnotetext{
Atousa Jafarian, Ph.D. candidate, Faculty of Economy and Management, University Putra Malaysia. Email: AtousaJafarian@Gmail.com.

Meysam Safari, Ph.D., senior lecturer, Graduate School of Business, SEGi University.
} 
Oil price effect is not always the same in oil-exporting and oil-importing economies. Although adverse effect of oil price increments is much more noticeable in oil-importing countries, oil exporters are also affected through their transactions with other nations. For example, Abeysinghe (2001) showed that high oil prices increase the revenue of net oil exporters like Malaysia and Indonesia, but they will also be exposed to negative effects in the long run through their trading partners such as Singapore. Even in a single economy, the impact of oil price fluctuation is not always the same across different sectors and industries. The magnitude and direction of impact may change for producers or consumers of oil or oil products. Understanding the nature and the degree of oil price effect on stock returns in each industry or on a larger scale in each sector can help investors and portfolio managers better diversify their portfolios by including the right stocks in times when there are expectations of rising or falling oil prices. Therefore, this study investigates the impact of oil price changes on various sectors of Malaysian economy.

Last decade witnessed a very volatile oil market, as well as the highest-ever record of oil price of US\$147 per barrel in July 2008, as depicted in Figure 1. Various events added to the disparity of supply and demand in this period. Some of the notable significant events are the invasion of Iraq by the US, severe strikes and unrests in Venezuela, maturity of several oil fields around the world (e.g., the North Sea, Mexico's Cantarell, and Saudi's Ghawar), oil supply disruptions in Syria, Sudan, and Yemen, and ongoing sanctions on Iran's oil export. On the demand side, continuous economic growth of China and India caused an upward trend in demand for oil in this period. However, shortly after the start of the global financial crisis in late 2008, the demand for oil dropped significantly, which led to a sharp decline in the oil price. Oil price rises are also attributed to several geopolitical factors such as Middle East tensions, concerns over Iran's nuclear program, and instabilities in Iraq and Nigeria.

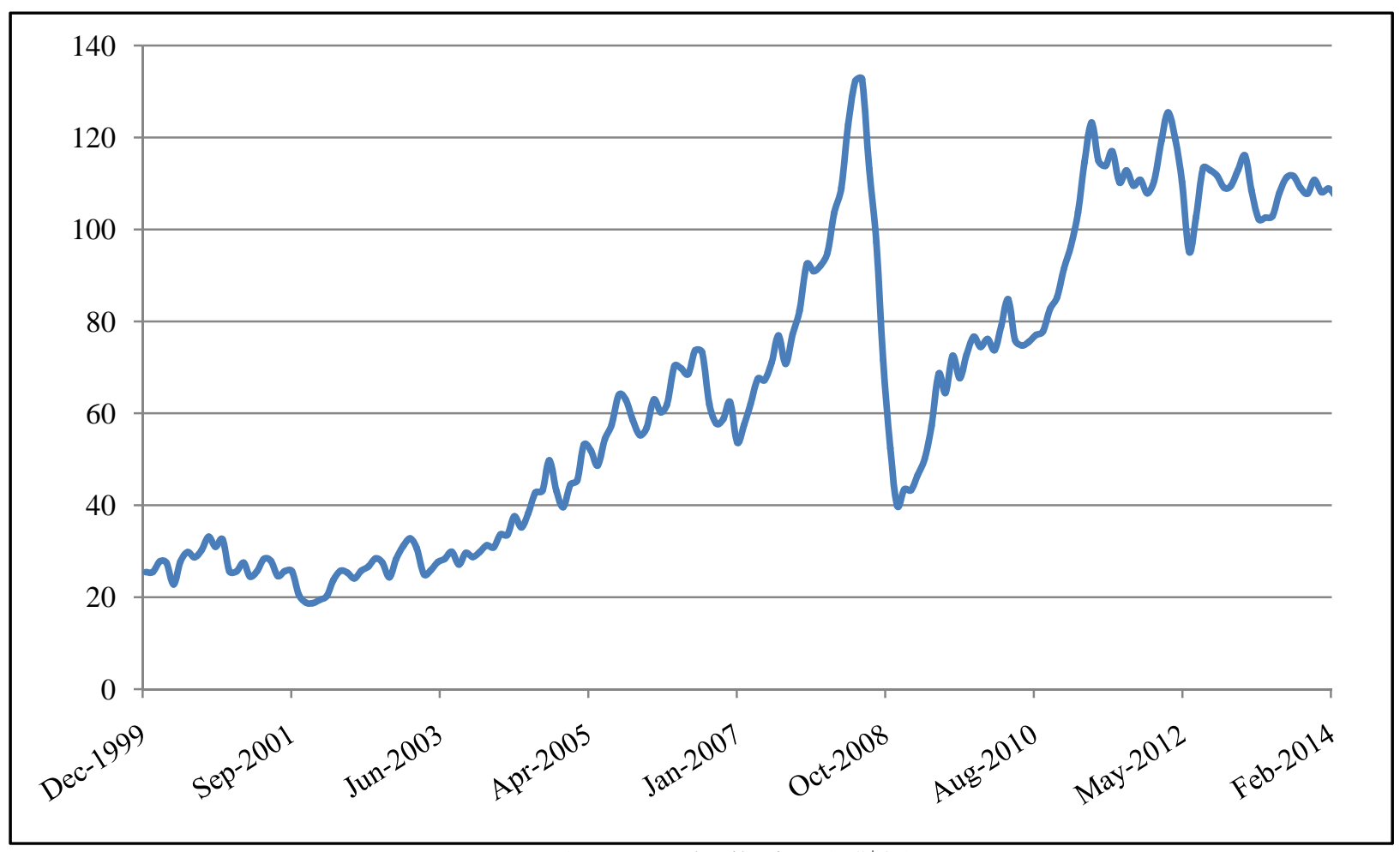

Figure 1. Brent crude oil prices (US\$/B). 
Maghyereh (2004) worked on 22 emerging economies including Malaysia. He found very weak evidence on the response of emerging stock markets to oil price shocks. Another study on emerging stock markets was performed by Basher and Sadorsky (2006). Contrary to the previous results, they found a strong evidence of oil price impact on stock returns in those countries. Le and Chang (2011) worked on the market reaction of both emerging and developed economies and found that Malaysia's stock market responds negatively to oil price fluctuations. Consequently, the findings of the previous studies are too diverse and further research needs to be carried out for more clarification on the issue. None of these studies looked into the effect of oil price change on the performance of different sectors. We argue that different sectors of the Malaysian economy react differently to the changes in oil price.

Malaysia is the 28th largest oil producer in the world and holds proven crude oil reserves of 4 billion barrels as of January 2013 (Energy Information Administration [EIA], 2013). After Indonesia became a net importer in 2008, it is now the only net exporter among ASEAN countries. The energy sector and particularly the oil and gas industry have been great contributors to the country's economy. Together, the export of crude oil and liquefied natural gas (LNG) accounted for 10.8\% of the country's gross exports in 2010 and the value of its oil exports averaged for almost 10\% of its GDP from 2006 to 2010 (Prambudia \& Nakano, 2012). Most of the country's oil production is being consumed domestically. Given the country's rapid growth in the manufacturing sector, the domestic demand for crude oil has been rising significantly throughout the years. However, as depicted in Figure 2, the oil reservoirs of Malaysia peaked in 2004 and since then, the oil production of the country has had a gradual decline. This situation has led to great concerns over the transformation of the country from being a net exporter to a net importer in the near future.

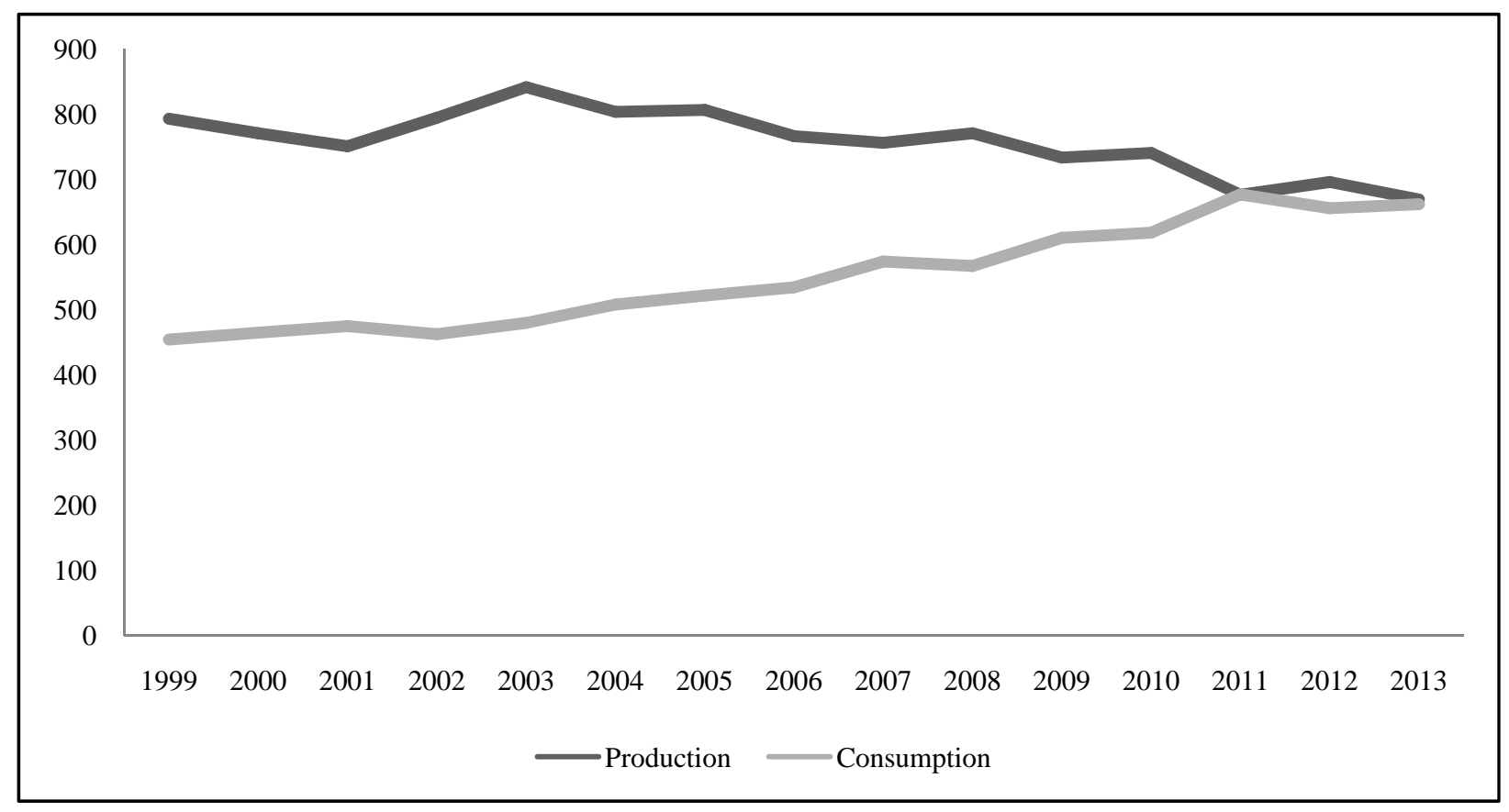

Figure 2. Oil production and consumption in Malaysia in the period of 1999-2013 (thousand barrels per day).

Rest of paper is structured as follows. The next section reviews existing literature; then, data and methodology used to conduct this study are introduced. Results of the analysis are presented in Section 4. Section 5 concludes the paper. 


\section{Literature Review}

Impact of oil price on stock market performance is well documented in the literature. Sadorsky (1999), using a vector auto-regression (VAR) approach, found that the US real stock return variations are attributed to oil price movements. The results of his study revealed that there is a negative relationship between stock prices in the US stock market and price of natural resources such as oil and gas. Kilian and Park (2009) looked at the supply and demand as the underlying causes of price changes and found that stock markets respond differently depending on causes of the oil price change. Positive shocks (caused by global economic expansion) stimulate the economy and lead to higher oil prices and higher returns in the short run. On the other hand, shocks driven by increased demand for crude oil which reflects concerns about future supply shortfalls cause lower stock returns and lastly, supply shocks do not have a significant impact on the stock returns.

Park (2007) expanded the research to the US and 13 European countries among which three of them were net oil exporters (the UK, Denmark, and Norway). He found that oil-importing countries (except Finland) experience a significant negative reaction to an increase in oil price. However, for net exporters, oil price shock had a different effect; in Norway, it was positively significant, in Denmark, it was negatively significant, and in the UK, it was insignificant. Arouri, Lahiani, and Bellalah (2010) examined Gulf Cooperation Council (GCC) countries which together they possess $47 \%$ of the proven reserves and they have control over $36 \%$ of the world oil exports. Results of the linear and nonlinear models indicated that in Qatar, Oman, Saudi Arabia, and the UAE, stock markets respond significantly to oil price changes, whereas in Bahrain and Kuwait stock markets, there is no evidence on the effect of oil price on the stock returns. To understand the dependency of China's stock market to oil prices, Nguyen and Bhatti (2012) used Chi-plot and Kendall-plot together with Copula method. Although China is the second largest oil consumer in the world, results did not show the existence of any tail dependence, which means that international oil prices do not have a linkage with China's stock market. In the study performed by Kapusuzoglu (2011), Johansen co-integration test and Granger causality analysis were applied to investigate the co-integrated and causality relationship between Istanbul Stock Exchange (ISE) and Brent oil prices for a period of 10 years using daily data. Johansen co-integration test determined the existence of a co-integrated relationship between the oil prices and each of the indices, which shows the long-term relationship between them. And one-way causality was found from each index to the oil price. Oil price uncertainty is another issue which was addressed by Wang, Wu, and Yang (2013). They found that stock markets in both oil-importing and oil-exporting countries show negative reactions toward supply and aggregate demand uncertainties. But oil-exporting countries are more affected by demand uncertainties.

While some studies have worked on general market index reaction to oil price fluctuations, Nandha and Brooks (2009) argued that since oil price affects each industry in a different way, studies based on sector/industry indices lead to more conclusive results. They argued that each industry reacts differently toward oil price changes. The nature and degree of impact normally depend on several factors. Whether the industry is energy-intensive, whether the industry is able to compensate the risk through transferring the shocks to the customers by increasing the price of its outputs, or how intensive the competition is within the industry. Industries that have oil-based inputs are particularly more vulnerable to oil price fluctuations. Mohamed (2012) performed a study on how much of the variations in European sectoral indices can be explained by oil price fluctuations. He found a high degree of sensitivity in most of the indices toward oil prices along with other risk factors such as exchange rate exposure and inflation. On an international scale, Nandha and Brooks (2009) focused only on transport sector across 38 countries. They found evidence that the oil price factor plays a 
determining role in stock returns in developed, G7, and European countries which have more mature economies. Conversely, the results were not significant in Asia Pacific, emerging, and Latin American countries.

Faff and Brailsford (1999), using the augmented market model, analyzed the sensitivity of the Australian industry equity returns to oil price changes. They found that oil price factor was more influential over some industries in Australia than the market factor. Two industries which were negatively affected by this factor were transport and paper and packaging industries. In contrast, oil and gas and diversified resources industries showed a significant positive sensitivity to oil price changes. Later, McSweeney and Worthington (2008) reexamined this study by investigating the reaction of Australian industry returns to macroeconomic risk factors including oil price, exchange rate, term premium, and market portfolio. Results were consistent with previous findings: Transportation industry had a negative link to oil price increases and energy industry displayed a positive link. Along with transportation, retailing and banking industry showed a negative response as well. Similarly, Cong, Wei, Jiao, and Fan (2008) employed multivariate VAR model on Chinese stock market and documented that only some major shocks negatively affect the oil company stock prices. Petrochemicals index and mining index returns increase with more volatilities in oil prices. Oil price shocks significantly explain the variations in the manufacturing index. The rest of the Chinese stock indices were not shown to be significantly affected by the oil prices.

\section{Data and Methodology}

Monthly data of stock prices of Bursa Malaysia and eight economic sectors of the country have been collected from January 2000 to March 2014. The selected sectors are from Global Industry Classification Standard (GICS) economic sector classification developed by Morgan Stanley Capital International (MSCI) and Standard \& Poor's (S\&P). They were chosen based on data availability for the whole period of study. Data on Financial Times Stock Exchange (FTSE) Bursa Malaysia Kuala Lumpur Composite Index (KLCI), MSCI world index, MSCI sectoral indices, and exchange rate are collected from Capital IQ database. The monthly Brent oil closing price data are collected from the US EIA Data Distribution System. Brent crude oil type has been widely used as the benchmark for oil pricing in previous studies. Interest rate on Malaysian Treasury Bill (MTB) has been gathered from International Monetary Fund (IMF) e-library database. Natural logarithm of the data has been taken before moving on to analysis stage. In order to measure the effect of oil price on Malaysia's stock market, MSCI world market index is used. Similarly, in order to measure this effect on each sector, FTSE Bursa Malaysia KLCI is used as the market index variable. Since the characteristics of the data (in terms of distributions) may change over time, data stationarity was tested. By using non-stationary data, the regression analysis may not reflect the real relationship among the variables. Moreover, according to Dickey and Fuller (1979), with the presence of unit root, the accuracy of forecasts in Granger causality analysis will be reduced. For avoiding such possibility, Augmented Dickey-Fuller (ADF) unit root test has been conducted prior to regression and Granger causality analysis.

A multifactor regression model is employed to measure the effect of oil price changes on the return of stock market index as well as eight economic sector indices. However, as suggested by literature, there are other macroeconomic variables that affect asset prices; hence, they need to be controlled. According to Fama (1991), the conventional way to select these variables is to look at what determinants previous studies have selected for analysis. Therefore, we chose three controlling variables, namely, market portfolio return, interest rate, and exchange rate, and their effect on the stock return will be investigated through the following model: 


$$
R_{i t}=\alpha+\beta_{1} R_{o t}+\beta_{2} R_{m t}+\beta_{3} R_{e t}+\beta_{4} R_{I R t}+\varepsilon_{t}
$$

where:

$R_{i t}:$ Return on index $i$;

$R_{o t}:$ Price changes in oil prices;

$R_{m t}:$ Return on market index;

$R_{e t}$ : Price changes in exchange rate of USD/MYR;

$R_{I R t}$ : Price changes in interest rate.

In order to test the causal relationship between oil price and stock returns, Granger's (1969) causality test was performed. According to Granger (1969), the results can be interpreted as a causal relationship. While regression analysis only identifies the existence of a relationship among the variables, Granger test reveals if one-time series can be used to predict the other time series. However, conducting Granger causality analysis is highly sensitive to lag length selection. The appropriate lag length for pairs of variables based on Akaike Information Criteria (AIC) is one lag. Therefore, the Granger equation tested was as follows:

$$
R_{i t}=\alpha+\beta_{1} R_{o, t}+\beta_{2} R_{o, t-1}+\varepsilon_{t}
$$

\section{Empirical Results}

Initial unit root test results indicate that all variables are stationary only at level one. Therefore, first differences of their natural logarithms (i.e., their returns) were computed. Results of unit root test on the returns are summarized in Table 1. Based on the results, all the variables are stationary at the base level and the null hypotheses of the existence of unit root can be rejected in all our variables at the significance level of $5 \%$. Therefore, there is no need for our data to be tested for unit root at second differences.

Table 1

\begin{tabular}{|c|c|c|c|c|}
\hline Variable & ADF $t$-stat. & PP t-stat. & At $95 \%$ critical value & Order of integration \\
\hline Oil price return & -10.71038 & -10.70676 & -2.878413 & $\mathrm{I}(0)$ \\
\hline Interest rate change & -6.618026 & -16.69181 & -2.878618 & $\mathrm{I}(0)$ \\
\hline Exchange rate change & -13.01262 & -13.02425 & -2.878413 & $\mathrm{I}(0)$ \\
\hline MSCI world return & -11.17581 & -11.33172 & -2.878413 & $\mathrm{I}(0)$ \\
\hline KLCI return & -10.35061 & -10.29445 & -2.878413 & $\mathrm{I}(0)$ \\
\hline Consumer discretionary return & -10.34822 & -10.35365 & -2.878413 & $\mathrm{I}(0)$ \\
\hline Consumer staples return & -11.08165 & -11.15264 & -2.878413 & $\mathrm{I}(0)$ \\
\hline Energy return & -10.70416 & -11.05531 & -2.878413 & $\mathrm{I}(0)$ \\
\hline Materials return & -12.80809 & -12.87165 & -2.878413 & $\mathrm{I}(0)$ \\
\hline Industrials return & -11.47075 & -11.53840 & -2.878413 & $\mathrm{I}(0)$ \\
\hline Financials return & -10.47988 & -10.44394 & -2.878413 & $\mathrm{I}(0)$ \\
\hline Telecom services return & -12.12929 & -12.11852 & -2.878413 & $\mathrm{I}(0)$ \\
\hline Utilities return & -9.310517 & -11.05811 & -2.878618 & $\mathrm{I}(0)$ \\
\hline
\end{tabular}

Result of Unit Root Test

Table 2 reports the results of OLS regression analysis on KLCI market index return as well as eight economic sectors of Malaysia for the period of 2000-2014. MSCI world index return is used as the relative market return for KLCI and similarly, KLCI return has been used as the relative market return of the eight 
economic sectors in this study. Results show that oil price change has a positive impact on the KLCI return at the significance level of $10 \%$. One percent change in oil price will make the index return to decline by 6.6122\%. Oil price changes also have a positive impact on consumer staples and energy sector returns. One percent increase (decrease) in oil price will generate a $9.3211 \%$ and $11.7385 \%$ increase (decrease) in consumer staples and energy sector returns, respectively. However, oil price changes negatively affect the returns in utilities and telecommunication services sector. One percent increase (decrease) in oil price will generate a $5.5323 \%$ and $10.8433 \%$ decrease (increase) in utilities and telecommunication services sector returns, respectively.

Table 2

Result of Regression Analysis on Malaysian Stock Market and Each Sector of It

\begin{tabular}{|c|c|c|c|c|c|}
\hline & Oil price return & $\begin{array}{l}\text { Relative market } \\
\text { return }\end{array}$ & $\begin{array}{l}\text { Exchange rate } \\
\text { change }\end{array}$ & $\begin{array}{l}\text { Interest rate } \\
\text { change }\end{array}$ & $F$-statistic \\
\hline \multirow{2}{*}{ KLCI } & 0.066122 & 0.359373 & -0.272107 & -0.088779 & \multirow{2}{*}{14.55959} \\
\hline & $1.775858^{*}$ & $4.720000^{* * *}$ & -1.159524 & $-1.966579^{*}$ & \\
\hline \multirow{2}{*}{ Consumer discretionary } & 0.030671 & 1.054664 & -1.012469 & 0.033640 & \multirow{2}{*}{113.5591} \\
\hline & 0.977449 & $16.79361^{* * *}$ & $-5.461514^{* * *}$ & 0.860986 & \\
\hline \multirow{2}{*}{ Consumer staples } & 0.093211 & 0.634598 & -1.354090 & -0.077886 & \multirow{2}{*}{55.97021} \\
\hline & $2.636216^{* * *}$ & $8.967563^{* * *}$ & $-6.482232^{* * *}$ & $-1.769056^{*}$ & \\
\hline \multirow{2}{*}{ Energy } & 0.117385 & 0.745403 & -1.008925 & -0.006118 & \multirow{2}{*}{26.63565} \\
\hline & $2.197316^{* *}$ & $6.971592^{* * *}$ & $-3.196692^{* * *}$ & -0.091969 & \\
\hline \multirow{2}{*}{ Financials } & 0.019381 & 1.191828 & -0.830409 & 0.018268 & \multirow{2}{*}{339.4722} \\
\hline & 0.993196 & $30.51728^{* * *}$ & $-7.203200^{* * *}$ & 0.751841 & \\
\hline \multirow{2}{*}{ Industrials } & -0.013676 & 0.964080 & -1.233666 & -0.030749 & \multirow{2}{*}{284.9461} \\
\hline & -0.732864 & $25.81254^{* * *}$ & $-11.18966^{* * *}$ & -1.323280 & \\
\hline \multirow{2}{*}{ Materials } & 0.004387 & 1.018011 & -1.779746 & -0.096132 & \multirow{2}{*}{48.35848} \\
\hline & 0.083314 & $9.659816^{* * *}$ & $-5.721048^{* * *}$ & -1.466187 & \\
\hline \multirow{2}{*}{ Utilities } & -0.055323 & 0.982689 & -0.514386 & 0.019713 & \multirow{2}{*}{103.9143} \\
\hline & $-2.029132^{* *}$ & $18.00883^{* * *}$ & $-3.193450^{* * *}$ & 0.580661 & \\
\hline \multirow{2}{*}{ Telecom services } & -0.108433 & 1.175730 & -0.864324 & 0.031818 & \multirow{2}{*}{96.46174} \\
\hline & $-3.144817^{* * *}$ & $17.03740^{* * *}$ & $-4.243002^{* * *}$ & 0.741094 & \\
\hline
\end{tabular}

Note. $^{*},{ }^{* *}$, and ${ }^{* * *}$ represent statistical significance at the levels of $10 \%, 5 \%$, and $1 \%$, respectively.

These findings are in line with previous studies, as the impact of oil price change varies across sectors. Energy sector directly benefits from increase in the oil price and consumer staples sector will pass on the inflationary effect to the consumers, resulting in higher earnings. On the other hand, utilities and telecommunication services sectors need to absorb the extra cost of energy (due to regulations as well as competition) and lose portion of their margins. Therefore, they are adversely affected. Results are inconclusive for other industries (consumer discretionary, financials, industrials, and materials). Our results indicate that the relative market return (positively) as well as exchange rate (negatively) have a significant impact on the market/sector return. Interest rate only has a significant negative relationship with market, but not with each sector.

Finally, to further study the relationship between oil price movement and stock market sensitivity of Malaysia, Granger causality test is performed and the results are shown in Table 3. The aim of Granger causality (with one month lag) test was to examine the potential causal effect of oil price changes and stock returns. The results reveal that oil prices Granger cause consumer staples, energy, telecom services, and industrial services to move. Therefore, one may conclude that the changes in oil price can cause the consumer staples, energy, telecom services, and industrial services sector returns to change. 
Table 3

Result of Granger Causality Tests

\begin{tabular}{lcll}
\hline Null hypothesis & $F$-statistics & $P$-value & Decision \\
\hline Oil price does not granger cause KLCI & 2.59886 & 0.1088 & - \\
Oil price does not granger cause consumer discretionary & 1.94197 & 0.1653 & - \\
Oil price does not granger cause consumer staples & 5.38264 & $0.0215^{* *}$ & Reject H0 \\
Oil price does not granger cause energy & 11.7604 & $0.0008^{* * *}$ & Reject H0 \\
Oil price does not granger cause financials & 1.42042 & 0.2350 & - \\
Oil price does not granger cause industrials & 4.50250 & $0.0353^{* *}$ & Reject H0 \\
Oil price does not granger cause materials & 1.57196 & 0.2117 & - \\
Oil price does not granger cause utilities & 0.01950 & 0.8891 & - \\
Oil price does not granger cause telecom & 3.26998 & $0.0724^{*}$ & Reject H0
\end{tabular}

Note. ${ }^{*},{ }^{* *}$, and ${ }^{* * * *}$ represent statistical significance at the levels of $10 \%, 5 \%$, and $1 \%$, respectively.

\section{Discussions and Conclusions}

This study examined the effect of oil price change on Malaysian stock market as a whole as well as its underlying sectors. Regression results indicate that the overall stock market (represented by KLCI) is affected by changes in the oil price. Results of Granger causality tests failed to support a causal relationship. Therefore, one may conclude that Malaysian stock market return is dependent on oil prices, possible as a major source of energy for the whole economy.

At the sector level, the main focus of this study, the energy sector, which includes the oil and gas firms, is positively affected by the changes in oil price. The higher the oil price, the more the earnings of oil and gas companies would be. Energy sector benefits significantly from the increase of oil price. This relationship is proved to be causal by Granger causality test: There is a causal relationship between oil price and the return of energy sector in Malaysia. In addition to that, consumer staples sector return is also dependent on oil price. The oil price change causes the consumer staples sector to change in the same direction. This direct relationship is based on the pass-through phenomena in this sector. Consumer staples firms will increase their output product price accordingly with the rise of oil price. Since their products are deemed necessary by consumers and considered as price-inelastic, they may actually benefit from this inflationary effect. Granger causality test confirms this argument by acknowledging the existence of a causal relationship between oil price hike and additional stock return in this sector of Malaysian economy.

On the other hand, utilities and telecommunication sectors have a negative relationship with oil price. An oil price increase will erode their profit margins and hence, they will lose portion of their earnings. Results of Granger causality test confirm the casual relationship in telecommunications sector, but not the utilities. Therefore, we can conclude that the negative impact of oil price change is statistically significant in these sectors. Finally, the results of the Granger causality suggest that the oil price changes will cause the industrial sector return to change. Using the results of regression analysis, the direction of changes would be negative. Therefore, oil price change will negatively affect the industrial sector return to change. The results of regression analysis for this particular sector were inconclusive; however, with lights of Granger causality tests, we may argue that the impact of oil price change on industrial sector return is not immediate and needs a one-month period to be fully absorbed. This indicates that the industrial sector will show a negative return only after a one-month period. 
Results of this study would be of importance for various parties. We have provided an international sectoral analysis of oil price impact in an emerging market, where there are very few studies of alike in existence. Moreover, investors may use our finding in their portfolio diversification. Our results can be used in portfolio management as we have identified the impact of oil price change on different sectors of market in Malaysia.

\section{References}

Abeysinghe, T. (2001). Estimation of direct and indirect impact of oil price on growth. Economics Letters, 73(2), 147-153.

Arouri, M. E. H., Lahiani, A., \& Bellalah, M. (2010). Oil price shocks and stock market returns in oil-exporting countries: The case of GCC countries. International Journal of Economics and Finance, 2(5), 132-139.

Basher, S. A., \& Sadorsky, P. (2006). Oil price risk and emerging stock markets. Global Finance Journal, 17(2), $224-251$.

Cong, R. G., Wei, Y. M., Jiao, J. L., \& Fan, Y. (2008). Relationships between oil price shocks and stock market: An empirical analysis from China. Energy Policy, 36(9), 3544-3553.

Dickey, D. A., \& Fuller, W. A. (1979). Distribution of the estimators for autoregressive time series with a unit root. Journal of the American Statistical Association, 74(366), 427-431.

Energy Information Administration [EIA]. (2013). Malaysia country report. Retrieved from http://www.eia.gov/countries/cab.cfm?fips=MY

Faff, R. W., \& Brailsford, T. J. (1999). Oil price risk and the Australian stock market. Journal of Energy Finance and Development, 4(1), 69-87.

Fama, E. F. (1991). Efficient capital markets: II. The Journal of Finance, 46(5), 1575-1617.

Granger, C. W. J. (1969). Investigating causal relations by econometric models and cross-spectral methods. Econometrica: Journal of the Econometric Society, 37(3), 424-438.

Kapusuzoglu, A. (2011). Relationships between oil price and stock market: An empirical analysis from Istanbul Stock Exchange (ISE). International Journal of Economics and Finance, 3(6), 99-106.

Kilian, L., \& Park, C. (2009). The impact of oil price shocks on the US stock market. International Economic Review, 50(4), $1267-1287$.

Le, T. H., \& Chang, Y. (2011). The impact of oil price fluctuations on stock markets in developed and emerging economies. Nanyang Technological University, School of Humanities and Social Sciences, Economic Growth Centre Working Paper No. 2011/03.

Maghyereh, A. (2004). Oil price shocks and emerging stock markets: A generalized VAR approach. International Journal of Applied Econometrics and Quantitative Studies, 1(2), 27-40.

McSweeney, E. J., \& Worthington, A. C. (2008). A comparative analysis of oil as a risk factor in Australian industry stock returns, 1980-2006. Studies in Economics and Finance, 25(2), 131-145.

Mohamed, A. (2012). Stock returns and oil price changes in Europe: A sector analysis. The Manchester School, 80(2), $237-261$.

Nandha, M., \& Brooks, R. (2009). Oil prices and transport sector returns: An international analysis. Review of Quantitative Finance and Accounting, 33(4), 393-409.

Nguyen, C. C., \& Bhatti, M. I. (2012). Copula model dependency between oil prices and stock markets: Evidence from China and Vietnam. Journal of International Financial Markets, Institutions, and Money, 22(4), 758-773.

Park, J. W. (2007). Oil price shocks and stock market behavior (Ph.D. dissertation, University of Missouri).

Prambudia, Y., \& Nakano, M. (2012). Exploring Malaysia’s transformation to net oil importer and oil import dependence. Energies, 5(8), 2989-3018.

Sadorsky, P. (1999). Oil price shocks and stock market activity. Energy Economics, 21(5), 449-469.

Wang, Y., Wu, C., \& Yang, L. (2013). Oil price shocks and stock market activities: Evidence from oil-importing and oil-exporting countries. Journal of Comparative Economics, 41(4), 1220-1239. 